\title{
Moral Commitment: A Preliminary Reflection on Nigeria
}

\author{
Aborisade Olasunkanmi \\ Philosophy Unit, Department of General Studies, LadokeAkintola University of Technology, Ogbomoso, Oyo \\ State, Nigeria
}

\begin{abstract}
This paper examines the extent of the moral commitment in Nigeria.Moral commitment is a species of commitment to a counter factual condition: that is, a standing commitment to live up to moral demands. The counterfactual-condition account of moral commitment can successfully defuse the worries they express about the effects of absence of moral commitment in our society. Today, Nigeria is now deeply infected by the deadly disease called immoral or unethical conduct. All Nigeria's institutions including, political, social and economic institutions manifest this symptoms of indiscipline. The Moral commitment is to restore the moral fiber of the Nigeria society. Nigerians should aspire to formulate a framework that will established a broad consensus on the kind of values the nation should uphold, as well as a standard against which the moral character of citizens will be measured.

The paper concludes that the shared moral values are the bedrock of any decent society, where selfishness and greed give way to the promotion of the common good
\end{abstract}

Key words: Ethics, Commitment, Morals, Values

\section{Introduction}

The word "ethics" comes from a Greek wordethos (custom) and has to do with "conduct,theory of what is ultimately good or worthwhile, of good conduct and character, or moral rightsobligations" (Boaz, 1972). Ethics are the customs or standards that a particular group or community acts on (Donalson, 1990). Omoregbe(1990) notes that ethics is concerned with the studies of human behaviour in relationship with others on the basis of rightness and wrongness. Velasquez (2002) also notes that ethics are the principles of conduct governing behaviour of individuals and groups. While the term "moral" refers to ability to judge between the right and wrong, good and bad and lawful and unlawful acts in relation to human actions and characters. It also means keeping to the code of conduct put forward by a society or group of people based on their customs, traditions and experiences.Morality is used to describe, justify and recommend the correct form of action; while value describes different beliefs of both a moral and non-moral nature, and normative refers to the overall framework within which moral and non-moral activities occur.

Moral values can be divided into two different categories: universal moral values and non-universal moral values. Universal moral values are those values that are shared by all peoples regardless of the cultural and moral position occupied by them. Examples of universal moral values include those enshrined in the Universal Declaration of Human Rights, such as liberty and equality. As decent and responsible members of the international community, we have a responsibility to adhere to these values and to commend them to others. Non-universal moral values are not as binding as the values referred to above. These are either inherent in or peculiar to a particular culture or nationality.Though it may not as binding as those of universal moral values, but communities in Africa have a way placing sanction on the erring individuals. This sanction serves as moral constraint on individual actions in the community.Moral constraints are rational constraints and so acting immorally is a way of being irrational. So African societies, as organized and functioning human communities, have undoubtedly evolved ethical systems - ethical values, principles, rules - intended to guide social and moral behavior.

This paper focuses on the extent of moral commitment in Nigeria. The act of indiscipline in Nigeria is quite worrisome. Thus, there is the need for planning how to fight that war. In this work the absence of moral commitment in Nigerian will be examine and effort of subsequent government leaders right from the period of General MuritalaMuhammed to President OlusegunObasanjo in confronting the problem shall be examined. Furthermore, we are going to deg deep to the root causes of the problem and in our conclusion we are going to suggest solution to the problem. 


\section{Commitment Problem}

Unethical conducts or acts of indiscipline are the most important problem confronting Nigeria as a country. This act of indiscipline has eating deep to the fabrics of the society. Efforts have been made by the succeeding government to wage war against the acts of indiscipline but failed. What can we do to generate widely shared moral repugnance against acts of indiscipline? This is the million-dollar question that still bedevils policy makers across the board. Fortunes in public funds have been spent experimenting with structures, programs and processes that could deliver the holy grail of moral renewal. These structures and programs have been at times built at the expense of obscuring the very content they were meant to promote. All this has arguably stemmed from the absence of a few vital ingredients necessary for moral regeneration to occur, including serious intolerance against corruption.

Various governments at the Federal, state and Local level, in Nigeria, have embarked on various programmes since independence to see that the wrong in the life of Nigeria are rewritten. For example: General MurtalaMuhammed administration between 1975 - 1976, carried out massive dismissals and compulsory retirementsof people alleged of corruption and other forms of indiscipline. General OlusegunObasanjo having a serious concerned with this problem of ethics ensures that the 1979 constitution of Federal Republic of Nigeria contained a six-page schedule setting forth a code of conduct for "public officers". A code of conduct Tribunal was put in place in the State capitals. The second Republic President ShehuShagari administration, 1979- 1983, put in place, Nigerian Ethical Revolution". In 1984 General MuhammaduBuhari and TundeIdiagbon fashioned out a Decree on War Against Indiscipline (WAI). This was intended to be used to fight all forms of indiscipline which were exhibited by Nigerians. General Ibrahim Babangida in 1985 introduced Mass Mobilization for Social and Economic Recovery (MAMSER). General SanniAbacha, in 1993, also put in place National Orientation Agency (NOA).

President OlusegunObasanjo administration (between1999-2000) established the Independent Corrupt Practices and other related offences Commission (ICPC). And also the Economic and Financial Crimes Commission (EFCC) which performs functions similar to that of ICPC. Obasanjo does this with the believe that the two agency (ICPC and EFCC) would play major roles in arousing moral commitment of both private and public organizations in Nigeria with a view to ensuring that transparency reigns supreme in Nigeria as a nation (Ogundele and Opeifa 2004c).

These noticeable unethical behaviours have negative effects moral commitment on the part of the citizens as well as the government agency in the performance of their duties, the situation has gone so worst that the nation has found it difficult to identify and thread the appropriate philosophical and developmental paths much less on ethical values (Aina 1992). Omotunde (1982) noted that the hardest job for the Nigerian child is how tolearn morals where none exists. Muganda (1999) discusses a number of factors that led to absence of moral commitment in Nigeria. These include several political factors, patronage and societal pressures, lack of transparency and proper enforcement of rules on regulation and government intervention in several spheres of public life and the expansion of the public sector bureaucratic inefficiency.

\section{The Causes Of The Absence Of Moral Commitment In Nigeria.}

In this work we want to examine those factors responsible for lack of moral commitment in Nigeria.

Leadership Based Causes:In an ideal society, leaders are expected to be role model. But the problem with Nigeria has remained the issue of bad leadership. Our leaders lack discipline and the citizen are following suit. Nigeria leaders have always been very poor or weak and very corrupt. Leaders' altitude towards indiscipline is more or less encouraging them to do more, hero worshiping and lack of accountability has remained the emblem of Nigeria leaders. Scholars blame this on long period of military rule but with the advent of civilian rule the act of indiscipline still remain the same.

Political Causes:They relate to actions and in-action on the part of those who are in authority.The listed items include: lack of action by government and its agencies on reported cases of act of indiscipline, corrupt government officials, political fanaticism, lack of concern for people's welfare, Conflicting rules and regulations, Poor management of resources and Lack of good government. Non compliance of members with rules and regulations, resulting in disorderly behaviour

Neglect of Societal Values and Norms: norms are not law but a way of life that has been adhered to by a group of people and it has been accepted and transmitted from generation to generation. Adherence to this rule is voluntary but the society has a way of sanctioning erring individuals. These include the following:- Gross unfaithfulness, dishonesty, laziness, lack of commitment to organization and nation, anxiety to attain great height without works worth unnecessary haste going to nowhere, lack of trust.

Religious Causes:Religion is supposed to teach moral and decent behaviour to its adherents.Causes of indiscipline that are linked with religion included: lack of proper religious moral teachings, lack of fear of God, lack of commitment to religious tenets, lack of disciplined religious upbringing, hatred of rival religious or 
religious sects member and religious fanaticism. The religious extremist like the BokoHaram is an additional factor.

Legal/Judicial Cause:They relate to the functioning of the legal and judicial systems inNigeria. Lists issues, based on the legal/judicial environments are as follows: lack of independence of the judiciary, lack of proper enforcement of laws, corrupt law enforcement agents, corruption in the judicial system, and very slow process of trial. Lack of good welfare for the judges that made many of them to take bribe and bypass judgment.

Civilization/Modernization Causes:society is not statics, society is dynamic, things are moving and new ways of doing things are being discovered. As good things are coming in bad ones are following suit. There are acts of indiscipline whose commission is attributable to civilization or modernization. They include:Foreign influence encroaching on our moral and cultural values, Imitating indecent foreign behaviours, showing films that are advertising indiscipline behaviours.

Management Slacks Cause:Poor management on the part of those at the helm of affair is another cause of indiscipline (Ogundele 2004). Many opportunists find themselves at the corridor of power because their party is at the center. Many of this people are inefficient and could not deliver. Some of them often disgrace the government of the day because as poor are they are they often overzealous and power drunk.

Motivational Causes:Motivation is a force driving people to do things, it is a drive which is variously linked with wages, instinct, purposes, goods, desires, wants, needs, and action behind every behaviour is a motive, therefore all behaviour to motivate, it is looked at as an involvement of the physiological and social aspect of human beings. Basically, motivation means an individual needs, desire and concepts that cause him or her to act in a particular manner, our interest in motivation is basically with respect to work, it is driven towards achieving certain objectives in an organization and sometimes regarded and a tool which may be in form of financial incentive such as provision of housing scheme for staff, health scheme, recreation center and end of the year bonus, promotion. Someorganization gives more attention to motivational system because it always contributes to the improvement of organization productivity. Here lack of motivation of all types in work organizations is listed as acause of acts of indiscipline.

General Educational Causes:Education is supposed to impart knowledge, to broaden the individual mind. It is also intended, to make him/her a better behaved member of thesociety. Lack of formal education, poor education, inadequate education, ignorance, wrong educational upbringing, lack of moral up bringing in schools, inadequate preparations for examinations and emphasis on paper qualifications (Ogundele 2004).

Training and Development Causes:Closely linked with education is training and development.Its purpose is to build in the individuals, various manipulative and intellectual skills and insights. This is to enable them to contribute meaning to the development of the society. Lack of training and development is listed as meaningfully one of the causes of indiscipline in Nigeria today.

\section{Conclusion}

There is the need to craft a shared vision of the desired collective and individual behavioral change. The Moral commitment is to restore the moral fiber of the Nigeria society. Nigerians should aspire to formulate a framework that will established a broad consensus on the kind of values the nation should uphold, as well as a standard against which the moral character of citizens will be measured.

Our leaders should be able to stand in the public mind as an ideal example of moral rectitude.Leaders should be models of disciplined conducts, leaders should be honest, faithful and disciplined for their society to have no problems, our leaders need to be reoriented to show good example. Put disciplined men and women at the head of nation's affairs and at all levels of institutions.

Values related approach include ; (a) Faithfulness in obeying laws, regulations, procedures and even God's laws (b) Honesty in all respects and aspects of the society, especially starting from leaders.(c) Reorientation towards valued behavior (d) Need to reshape values, behaviour and patterns of relationships and (e) Truthfulness by all and to all especially starting with leaders. (f) Upholding the principle of accountability

The politically based solutions include; (a) Government taking prompt actions in punishing offenders, (b) Government to improve the welfare of workers and the masses, (c) There should be no sacred cow. Government should deal sternly with law breakers regardless of their positions in the society, (d) Commitment on the part of the government - a committed government can find solutions to the many faceted problems of indiscipline. (e) Entrenchment of anti indiscipline acts in the constitution and (f) Government should enforce rules and regulations,

There is the need for a commitment to deal with the challenge of clarifying the role of civil society, especially at the grassroots level, in the country; a quest for moral regeneration. This is the sector that should drive the process of reaching a common agreement on shared moral values for our young democracy. Poor clarification of roles has at times meant that the people and communities vital to the success of the moral commitment are not optimally positioned to support it fully. 
Finally, the discourse of spirituality and religion, which has characterized much of the moral regeneration agenda in the past, may need to be kept in check, as this may alienate many of those who may feel uncomfortable with the association of morality with religion, including the belief that one has to be religious to be moral and has to believe in God to be good. Morality has governed societies long before the arrival of religion, which means that moral goodness can be found in people who have no religion. That shared moral values are the bedrock of any decent society, where selfishness and greed give way to the promotion of the common good, cannot be gainsaid. Our dark past has done little to foster a sense of national pride, but it did become a rallying point for many to fight for the common good.

\section{References}

[1] Aina S 1992. Personnel Management in Nigeria: A WorkCentral Approach, Lagos: Grey Resources Limited.

[2] Boaz, M. 1972. Code of ethics: Professional. InEncyclopedia of Library and Information Science,245-252.

[3] Donalson, J. 1990. Key issues in business ethics. London:Academy Press.

[4] Jefferson, R.N. \& Contreras, S. 2005. Ethical perspectivesof Library and Information Science graduate studentsin the United States. New Library World, 106

[5] Muganda AA 1999. The Corruption Scourge in Africa: itscauses, impact and control. In: K Frimpong, GJacques (Eds.): Corruption, Democracy and GoodGovernance in Africa: Essays on Accountability andEthical Behaviour. Botswana: South AfricanUniversities Social Science Conference, pp. 41-48.

[6] Ogundele OJ K 2004. Management Problems in NigeriaEducational institutions. Multi- disciplinary Journalof Research Development, 3(3): $17-22$.

[7] Ogundele OJK, Opeifa AZ 2004a. Importance of ethicaleducation in economic and social reconstruction. Nigerian Journal of Curriculum and Instruction,2(2):164 - 169 .

[8] Omoregbe J I 1990. Ethics for every Nigerian. Lagos:Shola and Associates.

[9] Omotunde S 1982. Ethical revolution: Talking loud andsaying nothing. The President, 1(2): 5-12.

[10] Velasquez MG 2002. Business Ethics: Concepts and Cases. New Delhi: Prentice-Hall of India PrivateLimited. 